\title{
End-game Strategies in the Swedish National Tabloid Industry
}

\author{
Karl ERIK Gustafsson
}

\begin{abstract}
Based on decades of comparative research on the national tabloid industry in the Nordic countries, a forecast is made, based on the product life cycle (PLC) theory, that the Swedish national tabloid industry will decline. As PLC theory is a blunt forecasting instrument, every precaution is taken; still a forecast is made that the No.2 tabloid will lose the present endgame to the market leader and disappear in 5-10 years time. End-game strategies as well as exit barriers are discussed in detail. The conclusions are valid for the national tabloid industries in the other Nordic countries following the same pattern of development. In passing, the question is raised of whether Internet publishing will change the rules of the game.
\end{abstract}

Keywords: national tabloid, PLC, declining industry, end-game strategies, exit barriers

\section{Introduction}

It took the Bonnier family, the biggest media owner in Sweden, 25 years to get the evening tabloid Expressen started in 1944 in Stockholm, the Swedish capital. The family council could not agree on whether the planned popular evening daily would hurt the reputation of or even overtake the position of its quality morning daily, Dagens Nyheter, as the biggest Swedish newspaper.

Some 25 years following its launch, Expressen hit a circulation record of 620,000 copies daily. Twenty-five years later, circulation numbers plunged to the lowest level ever. Now, 10 years after the plummet in circulation, which signalled a new negative trend, doubts could be raised as to whether the paper will be around another 25 years.

\section{The Theory of the Product Life Cycle}

There is a substantial risk that, in 5-10 years time, Expressen will lose the present endgame in the national evening tabloid industry to the current market leader, Aftonbladet, also published in Stockholm, but first launched in 1830. My doubts regarding the future of Expressen are based on the theory of the product life cycle.

\section{Two-century Old Theory}

Since the mid-1940s, the Swedish national tabloids Aftonbladet and Expressen, as an industry, have developed according to the s-formed curve called the product life cycle (Figure 1). 
Figure 1. Aftonbladet and Expressen: circulation weekdays 1945-2006

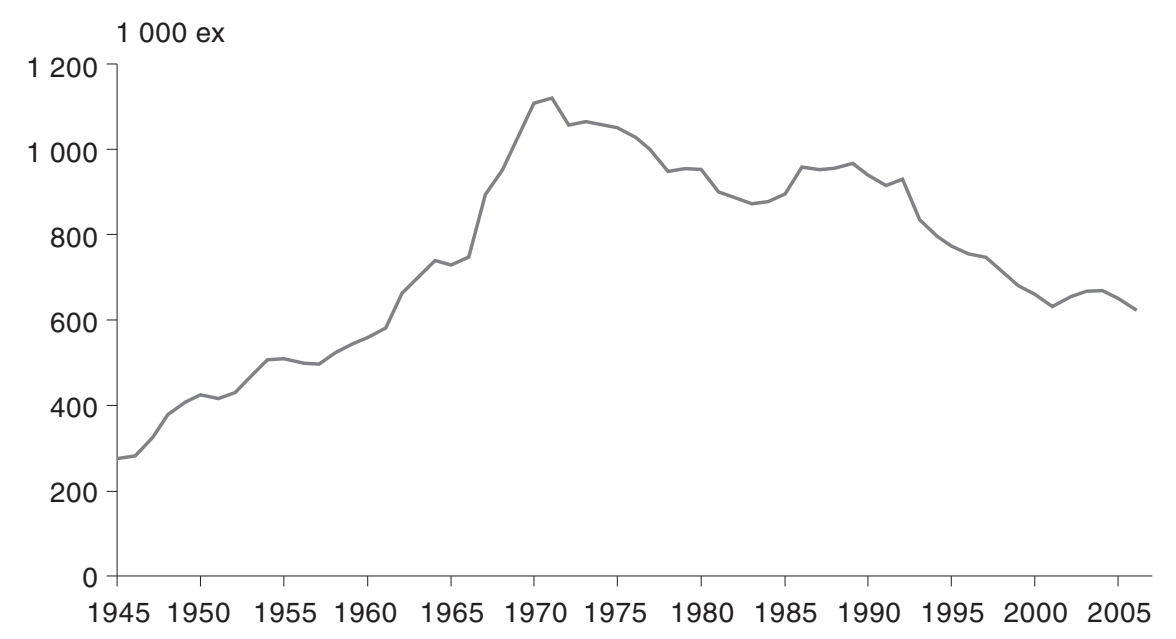

Note: The two regional evening tabloids, Kvällsposten and GT, are not included. They were bought by Expressen around 1990.

Source: TS-boken, yearly.

From the middle of the 1970s, when I started my research on the Swedish evening tabloid industry, PLC theory has been one of my starting points.

As a theory, PLC takes a resource-based competition view. Historically, this view dates from the beginning of the $19^{\text {th }}$ century and is based on works by the economist David Ricardo (1772-1823). In modern times, these theories have been developed at the company and industry levels by Edith Penrose (1914-1996) and Michael Porter (1947-). The best-known work by Penrose is The Theory of the Growth of the Firm (1959). Porter's foremost work is called Competitive Strategy (1980).

The starting point of the resource-based competition theories is Ricardo's concept of comparative advantages. These advantages consist of differences in resources between companies in an industry and their relative ability to make full use of their unique competencies.

\section{Approved Model of Analysis}

Any schematic presentation of the life cycle shows that the Swedish national evening tabloid industry is in the decline stage. The outline of Porter's work follows the life cycle pattern and accordingly the book contains a chapter on "Competitive Strategy in Declining Industries". The strategies that are suitable for the phase of decline are called "end-game strategies". The schedule adjoining the outline of the chapter is reproduced here. It works as a guide to my forecast.

Outline Competitive Strategies in Declining Industries

1. Structural determinants of competition in decline

Conditions of demand

Exit barriers

Volatility of rivalry 
2. Strategic alternatives in decline

Leadership

Niche

Harvest

Quick divestment

3. Choosing a strategy for decline

4. Pitfalls in decline

5. Preparing for decline

Source: Porter (1980), Chapter 12, pp. 254-274.

Porter's text builds mainly on a dissertation from 1979, completed at Harvard Graduate School of Business Administration, by his doctoral student Kathryn Rudie Harrigan. Her empirical foundation consisted of data from about 60 companies in seven industries. The dissertation was later published under a new title: Declining Demand, Divestiture, and Corporate Strategy. Today, Rudie Harrigan is Henry Kravis Professor of Business Leadership at Columbia University in New York.

The account of the Porter chapter on the phase of the decline starts with a description of the conditions of competition in this phase. Then follows a description of the strategic alternatives and what these demand from the companies. The choice of strategy is discussed in regard to the comparative advantages and disadvantages of companies in a declining industry. Lastly, Porter warns of common pitfalls in decline and gives general advice to competitors regarding how to prepare for decline. David Ricardo would have appreciated Porter's presentation.

\section{Blunt Forecasting Instrument}

The analysis I present here is solely based on PLC theory. The question is whether one should do this. Is it really a reliable theory? The decisive test of any theory is whether one can make safe forecasts by applying it. In this case, there are three types of uncertainty: the division into periods, the development pattern, and the dynamics of competition.

\section{Duration of Development Periods Uncertain}

The phases of development - introduction, growth, maturity and decline - are of different length in different industries and it may be hard to determine in which phase a certain industry is at a certain point in time. This is a minor problem, because I concentrate on one industry. Furthermore, I corroborate my conclusions by comparing them with results obtained for the development of tabloid industries outside Sweden. Nevertheless, one has to admit that the theory in question is uncertain as an instrument of forecasting.

\section{Diverging Development Patterns}

The life cycle curve is not always neatly s-formed. Some products may just skip over the introduction. In the 1950s, television showed a steep growth curve instantly. Industries may prolong their maturity by adding attractive features to their basic product - the augmented product concept - or in that way even turn decline into growth. When 
television changed from black and white to colour around 1970, a new growth phase followed with an even steeper growth curve.

Figure 2. National Evening Tabloids in the Nordic Countries 1945-2006

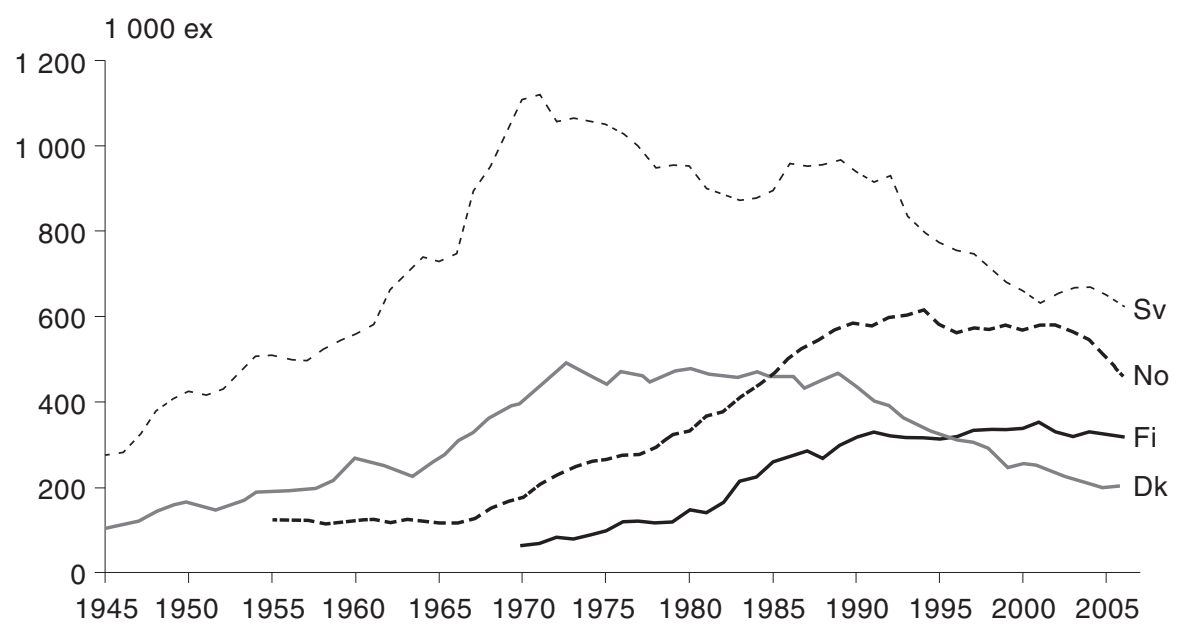

When I compare the development of the national evening tabloids in Sweden with the pattern of those of the other Nordic countries I feel assured. Comparable curves are presented in Figure 2. In all four Nordic countries, Denmark, Finland, Norway and Sweden, regional evening tabloids saw the introduction of the national evening tabloid as a new newspaper genre. They were issued in capital cities and were mainly sold in the capital region. The growth period started with a change in their business idea from a regional to a national newspaper.

This process began in Sweden in 1944 just with the start of Expressen, which did not wish to compete with the existing Aftonbladet concentrated on the Stockholm market where it was well established. The national tabloid Expressen gained such a lead in circulation that the Aftonbladet managers finally understood that it was no longer feasible to stick to the regional market idea. Aftonbladet followed suit and turned into a national tabloid. The competition between them led to further growth in the national tabloid market as more and more readers bought both tabloids. This dual buying was responsible for about one-third of the total circulation of the two tabloids.

In Denmark, the two regional tabloids, B.T. and Ekstra Bladet, copied the Swedish national tabloids, as did Dagbladet and $V G$ in Norway. National markets replaced regional capital markets. The Finnish national tabloid market started to grow in 1980 with the emergence of Iltalehti, to rival the region-based Ilta-Sanomat. Both became national tabloids.

In Finland, growth became rather drawn-out in time. In Denmark, attracting tabloid buyers using Bingo games prolonged maturity. This promotion method was practiced in Sweden in the 1960s during growth. Games propelled Aftonbladet into the national tabloid market.

The Swedish national tabloids were more successful than their Danish counterparts in prolonging their maturity period, to the extent that a new peak in the circulation curve was reached. Starting in 1984, supplements were issued systematically as circulation 
promoters. Aftonbladet relaunched its Sunday supplement under the editorship of Amelia Adamo. These supplement offers boosted the Swedish national tabloid industry: an additional product at a low price. The results of the supplements can be observed in Figure 3, which shows the circulation figures for Aftonbladet and Expressen. Aftonbladet gained a comparative advantage regarding the supplements, which was difficult for Expressen to match. Perhaps the newspaper was prevented from doing so to avoid interfering with Bonnier's publication of magazines.

Figure 3. Aftonbladet and Expressen 1945-2006

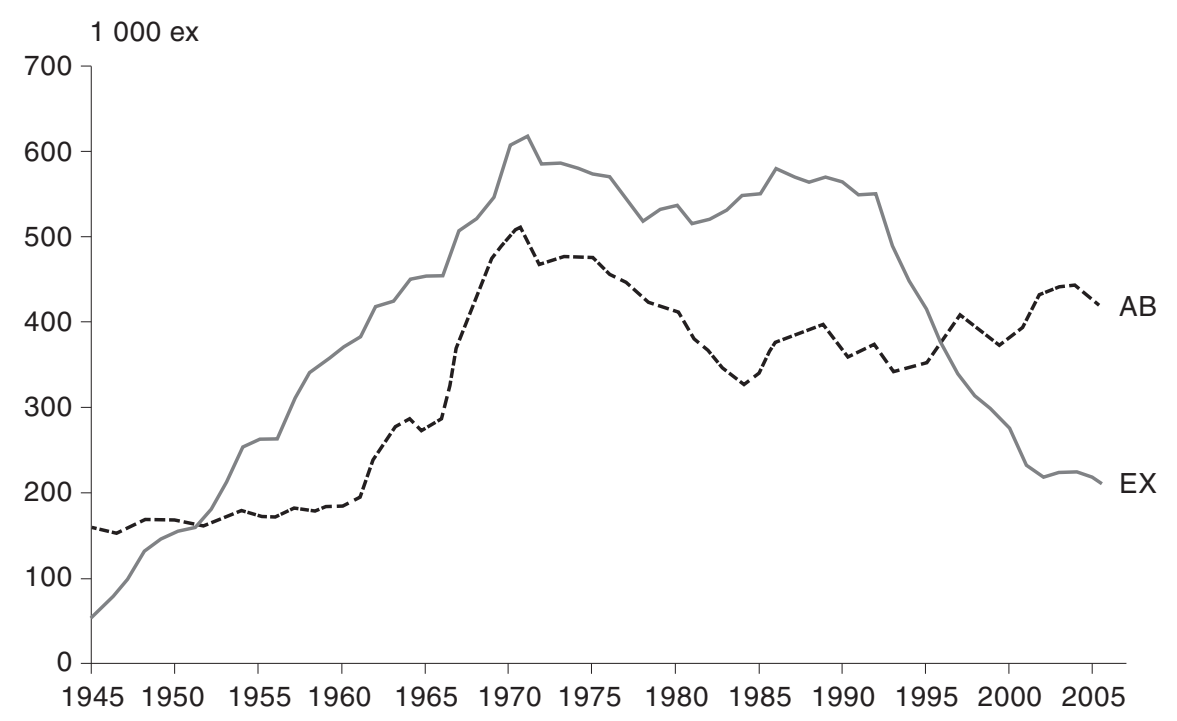

At this troublesome moment for Expressen, Bonnier made a desperate move. According to Alsing (2005), in the summer of 1987, Albert and Lukas Bonnier called upon Thorbjörn Larsson, chief editor of Aftonbladet and

offered him a gilt-edged contract if he left Aftonbladet to become CEO of the Bonnier magazine group. The package included a grand and well-paid job for (his wife) Amelia Adamo as well as a long stay for them in the US where they without hurry would travel from the east coast to the west coast and study the world of printed press.

Thorbjörn Larsson told the owner of Aftonbladet, the Labour Union, that he would stay only if he was appointed editor-in-chief. The owner acquiesced.

It belongs to the history of the Swedish tabloid that a similar offer was made by Bonnier in the middle of the 1960s to Sven Sörmark, who spearheaded the successful turning of Aftonbladet into a national tabloid. Bonniers' bid that time bore fruit directly, and Sörmark left Aftonbladet. After pressure by the Labour Union, disappointed with Bonniers' trick, Sven Sörmark was allowed to return to Aftonbladet after some years.

Returning to present time, eventually, first Amelia Adamo and then Thorbjörn Larsson left for the Bonnier camp and stayed.

But it did not take much time for Aftonbladet to fill the sudden vacancies and the Bonnier family once again failed to break Aftonbladet. However, it apparently comforted 
the Bonnier Group to at least have persuaded the successful magazine maker Amelia Adamo to join its ranks.

\section{Capricious Competition}

Of course, companies regard the life cycle curve as a challenge, particularly those in a declining industry. The competitive process of moves and responses may influence the course of the curve. The competition between Aftonbladet and Expressen during the 1960s pushed the circulation curve to the highest level owing to dual buying. The introduction of supplements prolonged the maturity phase.

I thought that with its enormous success in Sweden Expressen, given its comparative advantages, would choose to expand abroad during maturity on the Swedish market. My speculation was based on the fact that at the beginning of the 1980s Bonnier started Illustrerad Vetenskap, a popular science magazine in Denmark, Norway, and Sweden at the same time. After a few years, a Finnish version followed. Bonnier-owned $D a$ gens Industry, a tabloid financial daily, began its internationalization of the business tabloid. This started with Äripäev in Estonia. Why didn't Expressen go international, I wondered?

True, Expressen did engage in a daily in Riga, a daily established jointly by the Latvian government and Expressen, called Diena, but that was a quality morning daily. There were promising evening dailies to buy in Latvia, e.g. Rigas Bals, owned by the town of Riga for that matter, if Expressen as a risk minimizing strategy had wanted to take authorities onboard. Other markets in the east were just as open for the tabloid daily, a category that readers demanded most after the fall of communism. However, the inner compass did not work: In the east, the successful Swedish evening tabloid instead engaged itself in a traditional, quality morning daily.

Finally, Expressen found its way in the internationalization process and entered the Polish market as part owner of the tabloid Super Express, which was started by journalists who left another daily. For Expressen, however, it was too late for a wider diffusion of the concept. Instead the Ringier family, a newspaper owner in Switzerland, took over the tabloid markets in the east. In Switzerland, Ringier published the tabloids Blikk and Sonntags-Blikk, the two biggest Swiss papers. The tabloid Ringier started in 1994 in the Czech Republic was called Blesk, which simply means Expressen. It quickly became the biggest Czech paper. Ringier succeeded just as well in Hungary.

One may look indifferently on the failure of Expressen to go international. The Ringier family took charge of what the Bonnier family might have taken charge of. Family versus family, as the Swedish daily Sydsvenskan wrote when the Bonnier family in 1994 bought that paper from the Wahlgren family.

In any event, Expressen missed the train and in Sweden its circulation continued to drop. When the circulation of Aftonbladet plunged in the 1970s, it was cushioned by readers of social democratic leanings who began to grow in numbers when local and regional social democratic dailies all over the country had to close. Expressen had no such political base of support.

On the contrary, reader segments began migrating one after another: The sport fans were no longer interested in its hackneyed and monotonous sports reporting about alleged prearranged matches, immigrants who otherwise liked the paper for its layout, legible text and pictorial content could not possibly stand debasing banners calling on the authorities to "drive them out". To our advantage, they were not deported but did quit buying Expressen. 
When Bonnier bought Sydsvenskan, the regional evening tabloid Kvällsposten was included. The latter was started at the end of the 1940s to prevent Expressen from penetrating South Sweden. At Expressen, managers saw an opportunity to enlarge circulation by turning Kvällsposten into an edition. This idea was realized when Bonnier added the regional evening tabloid $G T$, relaunched in the 1940s as a defence against an expansion of Expressen at that time in Western Sweden. The new edition GT/Expressen appeared in February 1998 and the new edition Expressen/Kvällposten in April 1999. The expected synergies failed to materialize. The plunge of Expressen's circulation was too big.

\section{Common End-game Strategies}

The three warnings against using the theory as a forecasting instrument call for discretion. Porter recommends that one first carefully analyse the development and current situation of the industry to determine whether the theory can explain the development.

Undoubtedly, the evening tabloid industry is in decline. You cannot explain the decline as part of a business cycle. Expressen lost 350,000 copies. More than half of its circulation disappeared. The paper has recovered a couple thousand copies. From 1994 to 2002, the aggregated financial losses amounted to 130 million Euros. A couple hundred thousand of that has been recovered. But none of this helps us answer the question of how much longer Expressen can sustain itself before dying: five, ten or twenty years? My guess is that it will happen 5-10 years from now.

Rudie Harrigan and Porter developed four decline strategies following a study involving about 60 companies. Transferred to the evening tabloid industry, the Swedish tabloids, depending on position and comparative advantages, might choose to

1. Seek a leadership position: the market leader Aftonbladet may concentrate on becoming the sole national tabloid. In such a position, the paper may increase its profitability by economies of scale in spite of savings from today's industry cooperation, e.g. in distribution and the selling of ads. In order to become the sole national tabloid, the market leader has to invest continuously, always raising the stakes, never giving the others a helping hand, and above all not increasing the current very low cover price. The market leader may lower the competitors' exit barriers by buying their assets. Aftonbladet might acquire one or both of the regional tabloids, Kvällsposten and GT, from Expressen, or produce its "TV-Guide" or Sunday supplement, and so on.

2. Differentiate: The other tabloids may find a geographical niche or other niches as a survival strategy or as a halting-place of exit. GT might become a city tabloid in Göteborg, while such a solution in Malmö would not be viable for Kvällsposten, as Malmö has always been a weaker market for tabloids than Göteborg has. Expressen might create a niche in Stockholm, a solution to which I will return.

3. Disinvest in controlled forms: The strategy implies different ways for the threatened papers to increase their cash flow by eliminating new investment, cutting maintenance and maybe, but this is a bold proposal, testing a price increase. However, if the tabloids in question lack advantages of strength they will not succeed. The reputation of Expressen has been badly hurt and it has few friends.

4. Divest quickly: In Denmark, B.T., the second largest tabloid, turned into a more family-oriented magazine, but still it is tottering. As of April 2007, it is reported that it would offer more sex material on its pages, although not front page nudes. Once, 
B.T. was the sports paper of choice and represented "the Danish smile". It became the first tabloid in the Nordic area. A small-sized paper in Austria-Hungary inspired its creator during the First World War.

Expressen stands between the last two strategies. It will not do to try to augment products despite its close relations to the book publishing and DVD production by Bonnier companies. Here it is worth mentioning that one reason for Dagens Nyheter's purchase of the film company Svensk Filmindustri in 1973 was to be able to distribute videogrammes with Expressen. One might say that Dagens Nyheter foresaw how things would turn out. In the summer of 2006, thirty-three years later, the copy buyers of the printed tabloid were offered DVDs at a very low price, and in the summer of 2007 (April to September), readers were offered a complete set of James Bond movies: twenty movies, one by one, week by week, for 59 crowns each. The Bond series was followed, starting in September 2007 , by a 30 -week series of classic books by "the world's best authors".

Bonnier has entered the free sheet industry by launching Stockholm City. One alternative for Expressen might be a merger with Stockholm City in order to respond to the competition from Metro, the pioneering free daily tabloid.

\section{Pitfalls of Decline - And of Forecasting Decline}

Porter mentions a number of potential pitfalls in decline and one of them is the failure by the industry to recognize the downturn. "They look for optimistic signs since pessimistic ones are so painful." Firms in a declining industry might try to harvest without clear strengths.

These pitfalls of strategy might be regarded from another angle. They might be looked at as pitfalls of forecasting.

\section{The Key Role of Aftonbladet}

Should we believe that end-game is imminent in the national tabloid industry in Sweden? Is it not easy for the tabloids in question to avert the gloomy forecast? PLC theory is a blunt forecasting instrument precisely because of the dynamics of competition. Perhaps the incumbents, on the contrary, would like to quit the game, but not the market, and share the cake? However, it would be a shame if the evening tabloid industry were to end up as a cartel case for the competition authorities.

Does Aftonbladet really want to win the game, get rid of its competitors, and get the victory cup? Aftonbladet could easily help Expressen, as it does in a joint advertising selling operation, and by increasing the single copy price, and it did so not only once, but twice. On Monday the $26^{\text {th }}$ of June 2006, Aftonbladet raised its cover price from eight to nine crowns on weekdays, and from nine to ten crowns on Sundays. Wednesday the $28^{\text {th }}$ of June 2006, Expressen followed suit. On Monday the $25^{\text {th }}$ of June 2007, Aftonbladet raised its cover price from nine to ten crowns on weekdays. Tuesday the $26^{\text {th }}$ of June 2007, Expressen followed suit.

As expected the circulations fell but still the increase meant a surplus of revenue. In 2006, Aftonbladet gained 66 million crowns from copy selling and Expressen 50. The estimated price elasticity is -0.3 .

My forecast for Expressen is based on the assumption that the market leader Aftonbladet would settle for a knockout. It would give it the chance to grab an estimated 40 per cent of the circulation of its competitors of about 300,000 , i.e. a net gain of 120,000 
copies. That would bring about great economies of scale. Its circulation would reach more than half a million a day. This would be tempting enough, I suppose.

\section{Will Expressen Accept Losing?}

Will Bonnier really divest its investments in the national tabloid industry? The Harvard academics propose a number of exit barriers that every forecaster should have in mind.

The costs of exit might be too high. Perhaps managers, but not all employees, could be moved to other parts of the Bonnier Group. There might be long-term contracts preventing exit. Simply, it still makes sense to continue producing Expressen and its sister tabloids $G T$ and Kvällsposten.

There might be a number of strategic exit barriers. According to Bonnier, it might be of great value to continue producing Expressen, a comparative advantage. Are there synergies involved in issuing both the morning quality tabloid Dagens Nyheter and the evening tabloid Expressen? How important are the cultural pages of Expressen for promoting the book publishing business of Bonnier? What could be gained by closer relations between TV4, the Bonnier TV channel, and Expressen? Is it important for the identity of Bonnier? Is the paper significant for the liberal opinion camp, promoting non-socialist governments, which it succeeded in doing in 2006? Perhaps employment at Expressen is an important way of recruiting leading persons to other positions in the Group?

There might be emotional attachments to the tabloid. Expressen was started by one of the Bonnier family members, Albert Bonnier Jr. The tabloid became a pioneer in many fields. It created the modern national evening tabloid and gave it its position as a major newspaper category. Are there some persons at management level or among the owners whose all time favourite is Expressen? The employees whose jobs are threatened might react. An exit might hurt the pride of management as well as of owners. An exit might signal that Bonnier puts money before journalism. For these reasons, the owners might be prepared to transfer money from other parts of the Group to save Expressen.

There are differences between parts of the Bonnier Group. By and large newspapers are old and are seldom closed. Bonnier has never closed a newspaper. Among the published periodicals closure is common. Periodicals going below a certain circulation level are simply closed. Publishers have no mercy with periodicals. The family magazine Aret Runt, which was also started by Albert Bonnier Jr., was sold to the archrival Allers without any tears.

\section{New Rules of the Game?}

Gradually, the uncertain demand for the national evening tabloid is being determined by the Internet substitute.

Aftonbladet became the first newspaper on the Net in autumn 1994. In cooperation with the School of Journalism in Stockholm, it published cultural texts on the Internet. Half a year later, daily news was added. In the summer of 1995, Aftonbladet established an electronic database. In 1999, its Net paper became a separate company. At the latest turn of the century, about half a million visitors were registered during weekdays. About 80 percent of the texts of the printed version were also published electronically. Expressen followed the example, but Aftonbladet maintained the lead. 
Thus, both national evening tabloids are investing in the Internet substitute industry. If the substitute industry becomes even stronger, forecasting the print version of the national evening tabloid might become a purely academic matter. However, the most important question is whether the rules of the games will change such that the substitute becomes the real product. Will it perhaps be a chance for Expressen to make a comeback and regain its market leader position? This depends on whether we regard the conditions of competition as similar. Another important issue is whether the business model of the national tabloid -25 per cent of revenues from advertisers and 75 per cent from readers - will hold for the Internet market.

\section{References}

Alsing, Rolf (2005) Aftonbladet inifrån. 175 års kamp för tryckfrihet och ökad upplaga. Värnamo: Aftonbladet.

Berg, Thomas L. \& Shuchman, Abe (eds.)(1963) Product Strategy and Management. New York: Holt, Rinehart and Winston.

Chan-Olmsted, Sylvia M. (2006) Competitive Strategy for Media Firms. Strategic and Brand Management in Changing Media Markets. London: Lawrence Erlbaum Associates, Publishers.

Gustafsson, Karl Erik (ed) (1994) Media Structure and the State. Handelshögskolan vid Göteborgs universitet: Informations- och massmediegruppen (Skrift Nr 7).

Gustafsson, Karl Erik (1996) The Origins of the Swedish Tabloid. Expressen 1944-1994. Handelshögskolan vid Göteborgs universitet: Informations- och massmediegruppen.

Gustafsson, Karl Erik (1996) För folket eller eliten — Dagens Nyheter 1864-1989. I Gustafsson, Karl Erik (red) Dagspresstrategier - Förr och nu. Handelshögskolan vid Göteborgs universitet, Informations- och massmediegruppen (Skrift Nr 8).

Gustafsson, Karl Erik \& Rydén Per (red) (2002) Den svenska pressens historia, del IV. Stockholm: Ekerlids förlag.

Harrigan, Kathryn Rudie (2003/2007) Declining Demand, Divestiture, and Corporate Strategy. New York: Beard Books, (Reprint).

Porter, Michael E. (1980) Competitive Strategy. Techniques for Analyzing Industries and Competitors. New York \& London: The Free Press. 